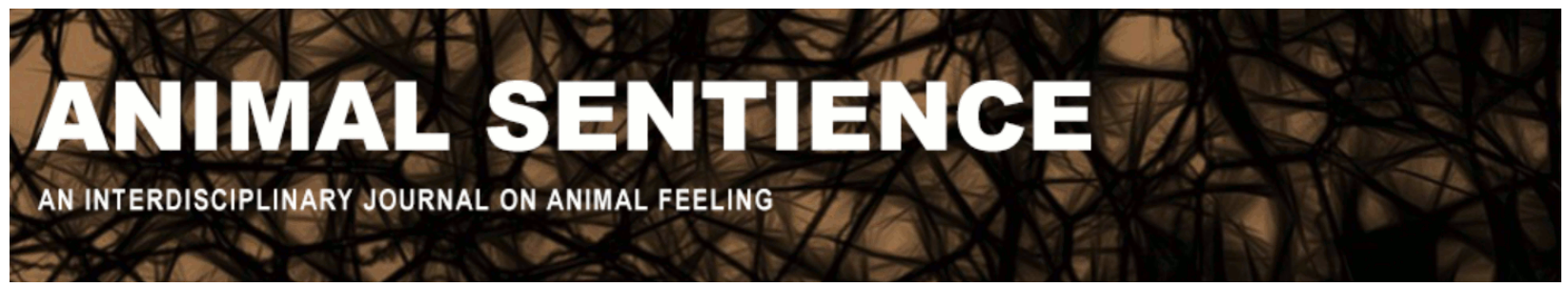

Edmondson, William H. (2018) Is superiority a necessary aspect of cruelty? Animal Sentience 23(15)

DOI: $10.51291 / 2377-7478.1387$

Date of submission: 2019-01-28

Date of acceptance: 2019-02-14 (c) 


\title{
Is superiority a necessary aspect of cruelty?
}

Commentary on Chapman \& Huffman on Human Difference

\author{
William H. Edmondson \\ School of Computer Science \\ University of Birmingham, United Kingdom
}

\begin{abstract}
Chapman \& Huffman argue that humans inflict cruelty without apparent concern because of their categorization of the victims as inferior. The supposed inferiority of non-human animals can be argued against on the basis of documentation and analysis of behaviour. Humans continue to inflict cruelty on their own and other species. It is not obvious that a sense of superiority is a necessary aspect of cruel behaviour. Nor is it obvious that further enlightenment regarding the cognitive status of non-humans will diminish cruelty.
\end{abstract}

William H. Edmondson spent his career working on aspects of Cognitive Science covering speech processing, signed language linguistics, and human-computer interaction, and eventually strayed into astrobiology and SETI. He is now retired but with an honorary position in the School of Computer Science at the University of Birmingham UK. He is also on the Advisory Board of METI. Website

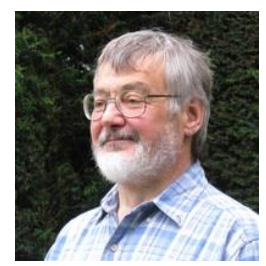

Chapman \& Huffman's (2018) (C \& H) short article "Why do we want to think humans are different?" is a provocation which suffers from brevity and simplistic analysis. These are strengths - they contribute to forcefulness in the overall argumentation - but they are weaknesses which obscure the bigger picture. The title is unhelpfully restated in different terms in the abstract: "Has the false sense of superiority been used to justify human cruelty to animals?"

C \& H essentially point out two things. The first is that non-human animals are capable of behaviours which evidence a range of skills in cognition and perception which rival the abilities of humans. Perhaps in humans the totality is unique, but in different species different skills and abilities match or exceed our own in the same domain. This is surely no longer a startling claim. C \& H cite various research publications, but omit several which could add weight to their argument (Birkhead 2012; Stamp Dawkins 1993; Povinelli 2000; Pearce 1997; Gould \& Gould 1994; Edmondson 2017).

The second point is more contentious. The issue of differences and whether they matter, in any particular sense, is very simplistically presented. The theme is categorization, with the argument being that humans are too ready to classify "others" as inferior (on whatever dimension is being considered). There is a wealth of psychological and linguistic work on categorization which is more nuanced than the picture offered by $\mathrm{C} \& \mathrm{H}$ (e.g., Smith \& Medin 1981; Craig 1986). Perhaps the most obviously accessible is "Women, Fire and Dangerous Things", by Lakoff (1987). It should be noted that in many instances, categorization is devoid of value-judgements. Languages sometimes divide the world of objects into genders, but the 
genders are grammatical constructs, not biological categories, and are value-free. Indeed, the conclusion has to be that perception of difference is not necessarily a value-judgement. Your method of making scrambled-eggs, marmalade, a fire ... whatever, does not mean that my method is inferior. Differences can just be differences.

There is historical evidence that humans considered non-humans capable of moral judgements. In 1379 some pigs were put on trial for murder and judged guilty and some were executed (Simon 2014). There was thus an equivalence of presumed moral capability, not an automatic assumption of difference with pigs being inferior.

Ultimately, we are asked to consider human cruelty to animals. A specific example is orangutans who are being deprived of habitat because forests are being destroyed in order to produce crops of palm oil. The issue of cruelty is complex here. The destroyer of the forest is certainly being greedy and thoughtless and may simply (perhaps through ignorance) assume the orangutans will move elsewhere. If there is cruelty, one is forced to consider whether it has to be done with knowledge of the outcome of the action. But then what of the food industries that buy and sell, or use, the palm oil? Are they being cruel? What of the consumer who buys the cake and doesn't see that it contains palm oil? No doubt the palm oil has been sold to the cake maker purportedly to improve the product or the process of making the product. Or perhaps it is simply because palm oil is better than snake oil?

Joking apart - where does the responsibility for cruelty in one's actions begin? There are campaigns to have palm oil removed from products, and they have some success. Is one guilty of cruelty to orangutans if one does not participate in such campaigning?

But there is a bigger question, it seems to me. Are humans unique in the biosphere on this planet because they can inflict cruelty on others (both conspecifics and other species)? You watch a cat playing with a nearly dead mouse. Is it being a cruel cat, or is it just being a cat?

You see your dog in severe discomfort from a cancer and agree with the vet that euthanasia is the kind way out for the beloved pet. You see your aunt dying in hospital with cancer (and managed pain relief), but euthanasia is not an option. You turn to another relative and say "You wouldn't do that to a dog". Who is being cruel, to whom, and where is the superiority?

Humans can be cruel to their pets unthinkingly. Having singleton pets can strike observers as cruel because members of the species seem to need a companion. Horses come to mind, and companion cat-dog pairs can often get along with a degree of comfort and calmness which the isolated individual pets don't display (they can get anxious and demanding - isn't that a form of cruelty?). Is keeping a pet at all an act of cruelty?

And is all this cruelty the result of humans thinking themselves to be superior? I think that is simplistic. We humans are capable of horrendous cruelty, both to other humans and to other species, but do we need a sense of superiority to behave this way? Does the target of our behaviour have to be seen as inferior or is it just that our cruelty reveals to us our own inferiority, and we must mask it?

Is it all a matter of categorisation? I'm not really convinced. Cruelty is horribly human. Unthinking cruelty is horribly human. Notions of superiority and inferiority may be invoked to explain, and sometimes even to justify (as in the Holocaust). But the cruelty may be uniquely human and can emerge without thought. Children can be cruel, and have to be taught the term, and the arguments against it. 
All of which is to say, and this is a matter of some regret, that a campaign of education about the sentience of non-human animals may not do much to address the cruelty to which they are subjected. The track record of the value of education in respect of the rights of women and minorities is not that impressive, and in these cases, the victims are still taking part in the campaigning.

And of course, we humans are trashing the planet, so in the end we will be suffering along with the orangutans.

\section{References}

Birkhead, T. (2012) Bird Sense: What It's Like to Be a Bird. Bloomsbury, London.

Chapman, C. A. \& Huffman, M. A. (2018) Why do we want to think humans are different? Animal Sentience 23(1)

Craig, C. (ed.). (1986) Noun Classes and Categorization. Typological Studies in Language, Volume 7. John Benjamins Publishing Company. Amsterdam.

Edmondson, W. H. (2017) The Sequential Imperative: General Cognitive Principles and the Structure of Behaviour. Brill/Rodopi.

Gould, J. L. \& Gould, C. G. (1994) The Animal Mind. Scientific American Library. (See also their book: The Honey Bee. 1995. Scientific American Library.)

Lakoff, G. (1987) Women, Fire and Dangerous Things: What Categories Reveal about the Mind. The University of Chicago Press.

Pearce, J. M. (1997) Animal Learning and Cognition. An Introduction. $2^{\text {nd }}$ edition. Psychology Press. Erlbaum (UK) Taylor and Francis Ltd.

Povinelli, D. J. (2000) Folk Physics for Apes. The Chimpanzee's Theory of How the World Works. Oxford.

Simon, M. (2014) Fantastically wrong: Europe's insane history of putting animals on trial and executing them. WIRED. Accessed January 27, 2019.

Smith, E. E. \& Medin, D. L. (1981) Categories and Concepts. Harvard University Press.

Stamp Dawkins, M. (1993) Through Our Eyes Only? The Search for Animal Consciousness. W. H. Freeman/Spektrum. 